\title{
Child Rights Protection in Ethiopia: Critical Analysis of the Statutory Rape Provisions of the Criminal Code and Their Application
}

\author{
Amare Tesfaye \\ School of Law, Dilla University, Dilla, Ethiopia \\ Email: amaretsf76@gmail.com
}

How to cite this paper: Tesfaye, A. (2017). Child Rights Protection in Ethiopia: Critical Analysis of the Statutory Rape Provisions of the Criminal Code and Their Application. Beijing Law Review, 8, 499-525. https://doi.org/10.4236/blr.2017.84028

Received: November 12, 2017

Accepted: December 17, 2017

Published: December 20, 2017

Copyright $\odot 2017$ by author and Scientific Research Publishing Inc. This work is licensed under the Creative Commons Attribution International License (CC BY 4.0).

http://creativecommons.org/licenses/by/4.0/

\section{(c) (i) Open Access}

\begin{abstract}
Children, due to their mental and physical immaturity, are among the vulnerable section of the society. States are thus required to provide special protection and care for children by making necessary legal and institutional arrangements. To this effect, Ethiopia has ratified international and regional human rights instruments meant to provide protection for children. It also included provisions protecting child rights in its constitution. These constitutional provisions have also found expression in the subsequent legislative reform that, among others, resulted in the adoption of a New Criminal Code in 2004. This Criminal Code replaces the provisions of the earlier 1957 Penal Code on statutory rape providing better protection for children against sexual abuse. Yet, gaps still persist both in the law and practice in terms of fully realizing the rights of children in Ethiopia. This article aims to examine the legal and practical protection of children by the statutory rape provisions of the Criminal Code in the Ethiopian legal system. In doing so, it attempts to evaluate the current statutory rape provisions of the Criminal Code against child rights standards as well as evaluating the practical application of the laws by courts and prosecutors.
\end{abstract}

\section{Keywords}

Child Rights, Criminal Code, Ethiopia, Sexual Abuse, Statutory Rape

\section{Introduction}

Children are among the most vulnerable sections of the society owing to the level of their mental and physical maturity preventing them from protecting their own rights and interests. Hence, plethora of human rights instruments and domestic legislations impose obligations on the part of the government to provide 
special protection to children. Such protection is premised on the realization that ensuring the rights of children is imperative for every country since it can advance a more equitable society, foster a healthier, more literate and, in due course, a more productive population.

Statutory rape is an illegal sexual activity against an individual when it would otherwise be legal if not for his/her age (Daniels \& Englund, 1998: p. 1; Donovan, 1997: p. 30). It refers to an act of sexual intercourse involving a person deemed by law to be too young to give his/her consent (Ibid). Hence, anyone having sexual intercourse with him/her has committed statutory rape regardless of the voluntariness of the victim. It is thus possible to conclude that the age of one's sexual partner is a crucially significant and material matter in distinguishing between lawful intercourse and criminal intercourse or statutory rape (Christopher \& Christopher, 2007: p. 77). As consent is not a requirement for its establishment, statutory rape is therefore committed even if the actor do not use force in the making of sexual intercourse with a person who is younger than the statutory age of consent. Here by "age of consent" mean the legal age at which an individual can legally consent to sexual intercourse.

The actual age of consent acceptable before the law vary from state-to-state, as do the punishments for offenders. For instance, in some states of US, there is a single age of consent ranging from 16 to 18 years old while the age of consent depend on one or more of the following factors in others: age differences between the partners, the age of the victim, and the age of the defendant (on this point see Glosser et al., 2004; Norman-Eady et al., 2003). It has been stated that Ethiopian laws do not clearly stipulate a minimum age below which children are said to be incapable of giving valid consent to sexual intercourse (Girmachew \& Yonas: p. 186). However, as can be understood from the cumulative reading of Article 620 (2a) and Article 626 of the Criminal Code the performance of sexual intercourse with a child who is between the age ranges of thirteen and eighteen constitutes the offence of statutory rape irrespective of consent on the part of the victim. Therefore, the age of sexual consent in Ethiopia is 18 years old both for boys and girls, making it a fixed one. Moreover, the presumption that children below the age of 18 cannot give a legally acceptable consent for sexual intercourse is absolute (Ibid). The main rationale for the offense of statutory rape is that persons below the age of consent lack the maturity and judgment to give sufficiently informed consent. Although the child may factually consent to intercourse, the law of statutory rape treats them as incapable of giving legal consent (Christopher \& Christopher, 2012: p. 215).

The performance of sexual intercourse with a minor ${ }^{1}$ or statutory rape has

${ }^{1}$ Here the author uses the word "minor" to refer to a person under the age of 18 . This definition is compatible with that provided in the 1960 Civil Code of Ethiopia and the Ethiopian Criminal Code provisions (Articles 52-56) dealing with infants and juvenile delinquents. In this article the author sometimes uses the word "child" instead of "minor". The author preference to use child sometimes not because it has different meaning from a minor, but solely for the purpose of using it as it was employed in the referenced texts or laws. Therefore, wherever the author uses the word child it means a minor, nothing else. 
many consequences on the latter. In acknowledgement of this fact, the African Charter on Rights and Welfare of the Child (ACRWC) states that the involvement of children in sexual activities is detrimental to them and thus must be prohibited. It has a direct and potentially permanent impact on the self-esteem of the victim and violates their right to human dignity, right to life, right to health and other rights. It may also deny them ability to control their sexual and reproductive choices and severely affect their physical, psychological, reproductive and sexual wellbeing. All these have the effect of snagging the implementation of their human rights. Thus, in order to provide protection for minors, most states throughout the world have criminalized statutory rape in their laws. This is also true for Ethiopia where statutory rape is a punishable criminal act (FDRE Criminal Code, 2004: Articles 620 (2a), 626 and 627).

International and regional human rights instruments have provide protection to children by prohibiting violence against them including sexual abuse. The Convention on the Rights of the Child (CRC) and ACRWC are the most relevant among these instruments in terms of emphasizing sexual abuse as a form of child abuse. These instruments set down the State Parties duties with regard to protection of the child from all forms of sexual exploitation and sexual abuse.

Ethiopia has ratified a number of international and regional instruments protecting the rights of the child including the CRC and the ACRWC. These instruments also have the status of the law of the land as provided in Article 9 (4) of the FDRE Constitution ${ }^{2}$ and standards for the interpretation of the human rights provisions of the FDRE Constitution as stated in Article 13 (2) of the FDRE Constitution ${ }^{3}$. The FDRE Constitution also incorporates provisions that specifically aim to protect the interests of children. These constitutional provisions are in turn reflected in the provisions of the Criminal Code where sexual intercourse performed with a minor is criminalized.

However, children continue to be victims of statutory rape in the country. This may be attributable to several factors. At the outset, the provisions of the Criminal Code have not provided equal protection to all children because of the existence of gendered provisions. Moreover, legislative measures alone cannot guarantee the eradication of sexual abuse and exploitation of children in Ethiopia. These measures need to be strengthened with effective application. Yet, there is evidence indicating that the judiciary and prosecution services have not been able to effectively apply the statutory rape provisions of the Criminal Code with adverse consequences for the protection of children. Addressing these legal and enforcement issues is essential to avoid sexual abuse and exploitation of children in Ethiopia.

\footnotetext{
${ }^{2}$ This article states that "all international agreements ratified by Ethiopia are an integral part of the law of the land."

${ }^{3}$ This article provides that "the fundamental rights and freedoms specified in this Chapter (Chapter three of the Constitution) shall be interpreted in a manner conforming to the principles of the Universal Declaration of Human Rights, International Covenants on Human Rights and international instruments adopted by Ethiopia."
} 
This article attempts to critically assess the statutory rape provisions of the Criminal Code and its effectiveness in advancing the rights of the child. It also tries to review the practice in Ethiopian courts and prosecutors in the enforcement of these provisions. Hence, the scope of this article is limited to the laws and practices regarding statutory rape. It only focuses on laws that criminalize sexual intercourse involving a minor that would be legal if not for the age of one or more of the participants. It does not include laws where the legality of the sexual acts is dependent on the relationship of the participants (e.g., incest, sex between teachers and students or doctors and patients). In addition, it does not include laws that criminalize specific sexual behavior (e.g., sodomy, bestiality) or deal primarily with prostitution, sexual exploitation, or enticement. In terms of methodology, the article employed qualitative method of research focusing on review of the relevant available literature, laws and case analysis.

The article has five sections including the introduction and concluding remarks. The first section tries to introduce the issue and indicate the contents of the article followed by the second section dealing with the various consequences that may accrue from statutory rape. The legal frameworks for the protection of children in general are discussed under the third section. The fourth section examines how the Ethiopian legal system addressed the crime of statutory rape. The critical examination of these rules from the perspective of the rights of children, more specifically from the perspective of the right to equality, is the focus of this section. This section also tries to explore the practice in the courts and among the prosecutors on the enforcement of laws on statutory rape before concluding remarks complete the article.

\section{Consequences of Statutory Rape on Victims}

As discussed in the introduction part, sexual intercourse with a minor has many consequences. This has been acknowledged in Article 27 of the African Charter on the Rights and Welfare of the Child (ACRWC), which states that, the involvement of children in sexual activities is detrimental to them and thus must be prohibited. It has a direct and potentially permanent impact on the self-esteem of the victim (Steel et al., 2004: p. 576; Roberts, 2000: p. 525 as cited in Hanzi, 2006: p. 3). It violates their right to human dignity, right to life, right to health and other rights and may deny them ability to control their sexual and reproductive choices. It may also severely affect their physical, psychological, reproductive and sexual wellbeing (Muringa, 2005: pp. 17 \& 58; McCabe, 2003: pp. 45-47).

The physical effects of statutory rape may include injuries to the vaginal and anal areas, lacerations, soreness, bruising, torn muscles, fatigue and vomiting. It could also have some gynecological consequences including vaginal stretching, miscarriages, stillbirths, bladder infections, infertility and so on (Ibid, p. 24).

${ }^{4}$ African Charter on the Rights and Welfare of the Child, adopted in Addis Ababa, Ethiopia on 11 July 1990 and entered into force on 29 November 1999. 
Beside the physical effects, statutory rape could have psychological effects, which may include short-term and/or long-term. Similar to other survivors of sexual violence, some of the short-term effects of statutory rape include anxiety, shock, intense fear, depression, suicidal ideation, and post-traumatic stress. Compared to adult victims of rape, statutory rape survivors suffer more of anger and depression because they are not in a position to struggle such challenges because of their age (Ibid). Long-term effects often include disordered eating, sleep problems, depression, and increased negative feelings about themselves (Ibid, pp. 24-25).

Sexual intercourse when carried out against minors impacts not only on their physical and psychological wellbeing but also affects their reproductive and sexual health thereby making them vulnerable to HIV/AIDS and other sexually transmitted diseases (STDs). Children's are highly vulnerable to STDs because their immune systems are not yet fully developed. For instance, it is said that, in a single act of unprotected intercourse with an infected partner, a girl has a $1 \%$ risk of acquiring HIV, a 30\% risk of getting genital herpes, and a 50\% chance of contracting gonorrhea (The Alan Guttmacher Institute, 1994 as cited in Elste \& Davis, 1997: p. 3). This list is not an exhaustive one since there may be other ramifications that accrue from the commission of an act of statutory rape.

All these have the effect of snagging the implementation of their human rights. Thus, in order to provide protection for minors, most states throughout the world has considered statutory rape as a punishable criminal act. Similarly, statutory rape is a punishable act under the Criminal Code of Ethiopia (FDRE Criminal Code, 2004).

\section{Legal Framework for the Protection of Children in Ethiopia}

The legal framework for the protection of children in Ethiopia consists of international and regional human rights instruments ratified by Ethiopia, the FDRE Constitution and subsidiary laws. This section of the article provides an overview of these legal frameworks.

\subsection{The 1995 FDRE Constitution}

The FDRE Constitution has devoted one third of its total provisions, starting from Article 13 to 44, to a subject dealing with "Fundamental Rights and Freedoms". This Constitutional Bill of Rights provides the fundamental legal framework for the protection of human rights in Ethiopia. The constitution follows a holistic approach in dealing with human rights by including all the three traditional generations of rights (civil and political rights, economic, social, and cultural rights, and solidarity rights) in a single human rights instrument or document.

Children, as human beings, benefit from the protections of all the human rights provisions of the FDRE Constitution. Besides, the FDRE Constitution devoted 
its Article 36 to exclusively deal with the rights of children. This provision specifically guarantees every child: the right to life (FDRE Constitution, 1995: Article 36 (1a)); right to a name and nationality (Ibid, Article 36 (1b)); right to know and be cared for by his or her parents or legal guardians (Ibid, Article 36 (1c)); right to not to be subject to exploitative practices, neither to be required nor permitted to perform work which may be hazardous or harmful to his or her education, health or well-being (Ibid, Article 36 (1d)); right to be free of corporal punishment or cruel and inhumane treatment in schools and other institutions responsible for the care of children (Ibid, Article 36 (1e)).

In addition to the aforementioned rights, the FDRE Constitution recognizes the basic principle, i.e., the best interest of the child ${ }^{5}$, to be considered by public and private welfare institutions, courts of law, administrative authorities or legislative bodies while undertaking actions concerning children (FDRE Constitution, 1995: Article 36 (2)). This is an acknowledgement of the fact that, in all likelihood, there would be times when certain rights of the child would come into conflict with the rights, prerogatives, and responsibilities of parents or guardian and with those of the state (Mower, 1997: p. 24). In such cases, as the language of Article 36 (2) of the FDRE Constitution stipulates that primary consideration should be given to the rights of the child. ${ }^{6}$ By making the rights of the child the primary, rather than paramount or prevailing, consideration, this provision provides the flexibility needed to give priority to other interests when circumstances so dictated, as in "extreme cases" (Alston, 1992: p. 9 as cited in Mower, 1997: p. 24). The problem with regard to the language of the FDRE Constitution is the absence of exceptions for the interests of the child to be paramount consideration, which is the case under the CRC. ${ }^{7}$ In fact, this problem can be rectified by the application of Article 13 (2) of the FDRE Constitution, which requires the interpretation of the fundamental rights and freedoms specified in Chapter III of the Constitution in a manner conforming to the principles of the international instruments adopted by Ethiopia. ${ }^{8}$

The FDRE Constitution also stipulates that juvenile offenders ${ }^{9}$ admitted to corrective or rehabilitative institutions, and juveniles who become wards of the State or who are placed in public or private orphanages, shall be kept separately

\footnotetext{
${ }^{5}$ This principle was first introduced in 1959 UN Declaration on the Rights of the Child and later included in the Convention on the Rights of the Child.

${ }^{6}$ In this regard, the FDRE Constitution has employed a similar wording with that of Article 3 of the CRC.

${ }^{7}$ Convention on the Rights of the Child, adopted and opened for signature, ratification and accession by General Assembly Resolution 44/25 of 20 November 1989 and entered into force on 2 September 1990. Regarding the practice of adoption, for instance, CRC under Article 21 requires the best interest of the child to be given a paramount consideration. Hence, in all actions of adoption, precedence should be given to the child's best interests. ${ }^{8}$ Ethiopia has ratified the CRC in 1991.

${ }^{9}$ The constitution is silent as to who are the juvenile offenders it has referred. However, under the Ethiopian criminal justice system, juvenile offenders are those young person's committing a crime between the ages of nine and eighteen years. This can be seen from the close reading of the provisions dealing with infants and juvenile delinquents (see FDRE Criminal Code, 2004: Articles 52-56).
} 
from adults (FDRE Constitution, 1995: Article 36 (3)). This obligation is imposed so as to protect children from being unfairly manipulated by adults.

The other important issue addressed under the FDRE Constitution concerning children is the right to equality. The FDRE Constitution under Article 25 provides that:

All persons are equal before the law and are entitled without any discrimination to the equal protection of the law. In this respect, the law shall guarantee to all persons equal and effective protection without discrimination on grounds of race, nation, nationality, or other social origin, color, sex, language, religion, political or other opinion, property, birth or other status.

This general equality and non-discrimination clause provides equal protection to everyone including children. However, to address the specific needs of children, the Constitution under Article 36 (4) provides that children born out of wedlock and children born of wedlock are equal. The comparison here is between those children born out of wedlock and those born of wedlock; the Constitution guarantees both the same rights (Ibid, Article 36 (4)). No distinction of any kind is allowed between the two on the basis that they are born out of wedlock or otherwise.

The last provision of the FDRE Constitution concerning children talks about orphans. The Constitution obliges the State to accord special protection to orphans. The State is also required to encourage the establishment of institutions which ensure and promote their adoption and advance their welfare, and education (Ibid, Article 36 (2)).

\subsection{Transnational Human Rights Instruments}

Child rights are an essential part of the transnational human rights systems. The rights of the child have been incorporated in various international and regional human rights instruments including: the 1924 League of Nations declaration on the rights of the child; the 1959 UNs declaration on the rights of the child; the International Covenant on Civil and Political Rights (ICCPR) ${ }^{10}$; International Covenant on Economic, Social and Cultural Rights (ICESCR) ${ }^{11}$; CRC; African Charter on Human and Peoples' Rights (ACHPR) ${ }^{12}$, and the ACRWC. Among these human rights instruments, the most important sources of the rights of children are the CRC and ACRWC. These instruments specifically deal with the rights of the child at the international and regional levels respectively.

\footnotetext{
${ }^{10}$ International Covenant on Civil and Political Rights, Article 24; this article entitles every child to have, without any discrimination as to race, colour, sex, language, religion, national or social origin, property or birth, the right to such measures of protection as are required by his status as a minor, on the part of his family, society and the State. Besides, it talks about the immediate registration of every child after birth, and every child right to have a name and to acquire a nationality.

${ }^{11}$ International Covenant on Economic, Social and Cultural Rights, Article 13 (3); This article imposes an obligation on the part of the State Parties to respect the rights of parents, and when applicable, legal guardians to choose for their children schools and to ensure the religious and moral education of their children in conformity with their own convictions.

${ }^{12}$ African Charter on Human and Peoples' Rights, Article 18 (3); this article imposes an obligation on the part of the State to ...ensure the protection of the rights of the child as stipulated in international declarations and conventions.
} 
According to Article 9 (4) of the FDRE Constitution, "all international agreements ratified by Ethiopia are an integral part of the law of the land". This means that the provisions of human rights treaties, which Ethiopia has ratified, are part and parcel of the law of the land. Hence, the provisions of human rights instruments like ICCPR, ICESCR, CRC, ACHPR, and ACRWC that deals with child rights are also relevant to know the child rights entrenched in the constitution as Ethiopia is party to all these human rights treaties. By making international human rights instrument an integral part of the law of the land, Article 9 (4) extends the protection of child rights in Ethiopia. This argument could also be supplemented by the provision of Article 13 (2) of the FDRE Constitution, which advocates for the interpretation of the provisions of Chapter III of the Constitution in consistence with the principles of UDHR, ICESCR, ICCPR and other transnational instruments adopted by Ethiopia (FDRE Constitution, 1995: Article 13 (2)). Consequently, we can say that, the rights of children protected in the FDRE Constitution are not limited only to the text of the Constitution but also to relevant provisions of international and regional instruments ratified by Ethiopia. Therefore, every child is not only entitled to the protections provided for in the Constitution, but also in those ratified international and regional human rights instruments. This would thus provide the beneficiaries or right-holders with an opportunity to choice of an instrument that offers a higher protection to their rights and invoke the same before court of law.

\subsection{Subsidiary Legislations}

The legal framework for the protection of children's rights in Ethiopia is not limited to the provisions of the FDRE Constitution and international and regional human rights instruments ratified by Ethiopia. These provisions are supplemented by and given expression in the subsidiary laws of the country. These laws, which are promulgated by the law making body, provide for more detailed substantive and procedural protections for children.

The most important pieces of legislation for the protection of child rights include Labor Proclamation No. $377 / 2003^{13}$; the Federal Civil Servants Proclamation No. 515/2007 $7^{14}$; Federal Revised Family Code and Regional Family Codes, and the Criminal Code. While there are a wide range of laws that are relevant to the protection of children, this article focuses on those laws that are directly relevant to the critical analysis of the statutory rape provisions of the Criminal Code.

\section{Statutory Rape in the Ethiopian Legal System}

The transnational human rights instruments that Ethiopia ratified have provide

\footnotetext{
${ }^{13}$ This proclamation under Article 48 (2) specifies 14 years old as the minimum age of limit to be eligible for concluding contract of apprenticeship. It also prohibited to employ persons under 14 years of age under Article 89 (2).

${ }^{14}$ This proclamation under Article 14 (1a) specifies 18 years old as the minimum age of limit to be eligible for a civil servant.
} 
protection to children by prohibiting violence against them including sexual abuse. The CRC and ACRWC are the most relevant among these since their provisions specifically address sexual abuse as a form of child abuse. ${ }^{15}$ These instruments set down the State Parties duties with regard to child protection from all forms of sexual exploitation and sexual abuse. For instance, the CRC stipulates that "States Parties undertake to protect the child from all forms of sexual exploitation and sexual abuse" (CRC, 1990: Article 34). Similarly, the ACRWC urges State Parties to take measures to prevent the inducement, coercion or encouragement of a child to engage in any sexual activity (ACRWC, 1999: Article 27 (1a)). State Parties are thus required to review their domestic legislations in line with the provisions of these instruments to ensure the protection of children from sexual abuse.

As indicated above, Ethiopia has ratified the CRC and ACRWC in 1991 and in 2000, respectively. As a party to the convention and the charter, the government is therefore required to harmonize its domestic laws with the provisions of the convention and the charter. Accordingly, the government of Ethiopia has undertaken a broad law reform program to ensure their harmonization with these conventions and the FDRE Constitution. ${ }^{16}$ In fact, the FDRE Constitution has no provision that explicitly provide protection to children against sexual abuse. However, the provision of Article 36 (d) of the FDRE Constitution, which states that "every child has the right not to be subject to exploitative practices, neither to be required nor permitted to perform work which may be hazardous or harmful to his or her education, health or wellbeing", impliedly indicates such protection; because the phrase "not to be subjected to exploitative practices" can be interpreted to include sexual abuse. This interpretation is normally in line with Article 13 (2) of the FDRE Constitution, which requires the interpretation of chapter three of the Constitution in a manner conforming to the principles of international instruments adopted by Ethiopia. The promulgation of the Criminal Code of 2004 replacing the 1961 Penal Code is part of this review process. In line with the provisions of Article 34 of the CRC and Article 27 of the ACRWC, the Criminal Code prohibits the engagement of persons under the age of eighteen in sexual intercourse.

The Code has also improved upon the previous Penal Code in areas such as non-prosecution in the event of subsequent marriage of the victim (Penal Code of Ethiopia, Proclamation No. 158/1957, Article 599) and in raising the age of consent to eighteen years. Article 599 of the Penal Code of Ethiopia reads as follows:

where the victim of rape, indecent assault or seduction, or abuse of her state of distress or dependence upon another, freely contracts a marriage with the of-

\footnotetext{
${ }^{15}$ Sexual abuse is one of the different forms of abuses that party states are required to protect according to Article 19 of CRC and Article 16 of ACRWC

${ }^{16}$ The FDRE constitution provides the umbrella provision for the protection of the rights of the child under Article 36, which relates to the protection of the rights of the child that have been enshrined in CRC and ACRWC.
} 
fender, and where such marriage is not declared null and void, no prosecution shall follow. Where proceedings have already taken place and have resulted in a conviction, the sentence shall terminate forthwith.

From this provision, it can be inferred that the law exempted a rapist if he later married the girl. Even when proceedings were instituted against the rapist, such proceedings shall be terminated if he contracts a marriage with the victim. This kind of legislative reform is a positive step in the protection of child rights as it will not leave the perpetrator unpunished for the criminal act he/she has committed. This reflects the strict adherence of the criminal law in protecting the public interest beyond the interest of the individuals, specifically the victim. Yet, there are some gaps in terms of providing equal protection to children. The following sections deal with these issues.

\subsection{Crime of Statutory Rape in the New Criminal Code}

As discussed above, statutory rape is a punishable act under the Criminal Code of Ethiopia. The provisions that criminalize and penalize this kind of criminal offence are incorporated in Title IV, Chapter I, Section I of the Criminal Code, which deals with "crimes against morals and the family". Thus, in this section, the writer examines these provisions in detail.

A person is said to have committed a crime and as a result bear criminal liability where the three cumulative elements of crime are fulfilled. In this regard, Article 23 (2) of the Criminal Code provides "a crime is only completed when all its legal, material and moral ingredients are present." The legal element relates to whether the given act or omission is prohibited and punishable by the criminal law (FDRE Criminal Code, 2004: Article 2 (1\&2)), the material element (actus reus) refers to the commission of the act or omission by offender in violation of the express prohibition of the criminal law, and the moral element (mens rea) refers to the moral blameworthiness of the offender (Elias, 2013: pp. 47-51). As a category of offenses listed in the Criminal Code, a person alleged to have been committed statutory rape will be held criminally liable only when these three cumulative conditions are satisfied. According to the cumulative reading of Articles $626^{17}$ and $627^{18}$ of the Criminal Code, there are two requirements that must be fulfilled for the crime of statutory rape under Ethiopian criminal law: first, the defendant must engage in sexual intercourse with the victim; and second the victim should be under the threshold age of consent. However, these two conditions

\footnotetext{
${ }^{17}$ Article 626 (1\&2) of the Criminal Code provides: 1) Whoever performs sexual intercourse with a minor of the opposite sex, who is between the ages of thirteen and eighteen years, or causes her to perform such an act with her, is punishable with rigorous imprisonment from three years to fifteen years. 2) A woman who causes a male minor between the ages of thirteen and eighteen years, to perform sexual intercourse with her, is punishable with rigorous imprisonment not exceeding seven years.

${ }^{18}$ Article 627 (1\&2) of the Criminal Code provides: 1) Whoever performs sexual intercourse with a minor of the opposite sex, who is under the age of thirteen years, or causes her to perform such an act with her, is punishable with rigorous imprisonment from thirteen years to twenty-five years. 2) A woman who causes a male minor under the age of thirteen years, to perform sexual intercourse with her, is punishable, with rigorous imprisonment not exceeding ten years.
} 
are not sufficient to make the person criminally liable. There is a need to further prove the fulfillment of the mental element (mens rea).

In some states, unlike ordinary rape, which requires the perpetrator to have a culpable state of mind, crime of statutory rape is considered as a strict liability crime $^{19}$. No criminal intent is required to establish the crime of statutory rape. As said above, a crime usually requires an actus reus, or guilty action and a mens rea, or guilty mind. The actus reus in the case of statutory rape is the act of having sexual intercourse with a victim under the age of legal consent. The mens rea however does not apply to the crime of statutory rape in states that consider it as a strict liability crime and therefore, any defense based on the mental state of the offender, will not be allowed. For instance, consent by the victim, even if freely given, will not be taken into consideration as to the establishment of guilt. Being mistaken often does not matter. This is thus an exception to the general defense of mistake of fact, which states that if the defendant believed there exist certain facts, which had they been true would have rendered the action lawful, then he/she was not guilty because he/she was incapable of entertaining the intent necessary to constitute the crime.

When we see the Ethiopian Criminal Code concerning statutory rape, at first glance, it seems that the mens rea element is missing and strict liability is applicable; because, as can be seen from the provisions of Articles 620 (2a), 626 $(1 \& 2)$, and $627(1 \& 2)$ of the Criminal Code, mens rea is not expressly embodied. However, this is not true as the concept of strict liability in criminal offenses is not envisaged in the Criminal Code. The mens rea is implied in these provisions, because Article 59 (2) of the Criminal Code provides that "crimes committed by negligence are liable to punishment only if the law so expressly provides by reason of their nature, gravity or the danger they constitute to society." And the second paragraph of Article 57 (1) of the Criminal Code states that "a person is guilty if, being responsible for his acts, he commits a crime either intentionally or by negligence." The cumulative reading of these provisions tells us that all offenses require intention unless a specific provision which defines a given offence expressly states its mens rea as negligence. Any provision that does not express negligence as the required moral guilt is thus interpreted as requiring criminal intention (Elias, 2013: pp. 132-3, 365). Therefore, the crime of statutory rape under Ethiopian criminal law requires criminal intention as its mens rea. It is thus possible to argue that the Ethiopian criminal law requires the prosecution to prove that the defendant had any mens rea as to the victim's age, and consequently a defendant's honest and reasonable belief as to the victim's age can be used as a defense. Having said this, the following few paragraphs assesses the specific statutory rape provisions of the Criminal Code.

The first provision relevant for the issue of statutory rape is Article 620 (2a) of the Criminal Code. This article stipulates that, "where the crime of rape is com-

${ }^{19}$ Strict liability in the criminal law is "imposing criminal responsibility for commission of the conduct prohibited by the statute without requiring proof of any culpable mental state." (Carpenter, 2003: p. 315). 
mitted on a young woman between thirteen and eighteen years of age... the punishment shall be rigorous imprisonment from five years to twenty years". This provision talks about the crime of rape committed on a young woman between thirteen and eighteen years of age. As a crime of rape, it requires absence of consent on the part of the victim, which is not the case in the crime of statutory rape. This provision indicates that the requirements for the prosecution of ordinary rape are needed to be met for instituting legal action against a person committing a crime of rape against a girl child, who is within the specified age limit. In order to prosecute a person for committing crime of rape under Article 620 (1) of the Criminal $\operatorname{Code}^{20}$, three requirements need to be fulfilled. First, the act must be committed against the will of the woman by the use of violence or grave intimidation; second, there should have sexual intercourse; and finally, it should be committed outside wedlock ${ }^{21}$.

As explained in the introductory part of this article, consent is not a requirement for statutory rape. If so, two questions can be raised here. First, if consent is not required, why Article 620 (2a) is formulated like that? Second, do the Criminal Code inconsistent with the provision of the Federal Family Code on the age of marriage, because of the requirement of the commission of the criminal act "out of wedlock"?

As far as the first question is concerned, it is important to understand the two categories of statutory rape: consensual and non-consensual statutory rape (Elste \& Davis, 1997: pp. 2-4). In the former case, consent is given though it is not legally acceptable due to the age of the person giving the consent, where as in the latter case there is no consent at all. For the writer, Article 620 (2a) is thus formulated to deal with the latter situation. This has benefit for the better protection of the minor child as the penalty in the two situations is different. For instance, compare the provision of this Article and Article 626 (1) of the Criminal Code. The penalty imposed under the former article is more severe than the penalty imposed under the latter article, which could have a more deterrence effect and consequently provide better protection to the girl child. It is also important for their better protection as it provides the prosecutor an opportunity to lodge an alternative suit and as a result, anyone having sexual intercourse with a girl

\footnotetext{
${ }^{20}$ Article 620 (1) of the Criminal Code states that: Whoever compels a woman to submit to sexuai intercourse outside wedlock, whether by the use of violence or grave intimidation, or after having rendered her unconscious or incapable of resistance, is punishable with rigorous imprisonment from five years to fifteen years.

${ }^{21}$ This requirement shows that "marital rape" is not a criminal act under the Ethiopian legal system. From this it can be inferred that husbands who force their lawful wives to have sexual intercourse are exempted from punishment, despite the physical and psychological trauma suffered by women as a result of their actions. This may be justified, among others, by the states eagerness to maintain marital privacy and harmony, the belief that woman has irrevocably consented upon marriage (implied consent theory of Sir Matthew Hale), belief that a woman was incorporated into the person of her husband after marriage (unity of the person theory) and the evidentiary problems inherent in proving lack of consent in an ongoing marriage relationship. However, there are also many states, such as South Africa, Ireland, Canada, the United States, New Zealand, Malaysia, Ghana to name but a few, that criminalized marital rape arguing that it is against the right to equality, right to dignity and bodily integrity of woman.
} 
child could not go unpunished. Alternative suit in the case at hand has the benefit of avoiding unnecessary losing of the case due to lack of evidence proving the "lack of consent" in the commission of the alleged crime of rape.

Apropos the second question, the writer has a negative answer. To begin with, the marriageable age is exclusively governed by a special law, the Family Code. Thus, it is difficult to assume that the provision of Article 620 (2a) is allowing marriage below the marriageable age provided under the Family Code, that is, below the age of 18 years old (Revised Family Code, 2000: Article 7) ${ }^{22}$. Second, it specifically acknowledge the marriageable age provided in the Family Code by making the conclusion of marriage with a minor apart from circumstances permitted by relevant Family Code as crime and punishable (FDRE Criminal Code, 2004: Article 648).$^{23}$ Thus, in order to give effect to both provisions of the Criminal Code, they should be interpreted positively. Accordingly, there is no inconsistency between the two codes.

The second relevant provision governing the crime of statutory rape is Article 626 of the Criminal Code. According to Article 626 (1) of the Criminal Code anyone who performs sexual intercourse with a girl child (between the ages of 13 and 18 years) or causes the latter to perform such an act with him, is punishable with rigorous imprisonment from three years to fifteen years. Pursuant to this provision, the person is liable in two situations: for performing the act or causing the minor to perform the act. Thus, unlike Article 620 (2a), the provision of this article protects the female minor from both consensual and non-consensual sex by avoiding the requirement of absence of consent for establishing the crime of statutory rape. Consequently, the law has made minors incapable of giving valid consent for performing sexual intercourse. This is in line with the provision of the civil code that makes minors incapable of involving in juridical acts based on the presumption that they cannot give informed consent (Civil Code of Ethiopia, 1960: Articles 192, $193 \&$ \& 198). This protects minors from being abused by the aged persons by taking their mental immaturity (Henry \& Cunningham, 2009: p 1).

Sub-article 2 of Article 626 governs statutory rape committed against the male minor between the ages of thirteen and eighteen years. This provision identifies female as abusers. Thus, it can be argued that, statutory rape occurs as a result of general power imbalance between the participants of sexual intercourse rather than as a result of gender based dominance pattern. ${ }^{24}$ Though this provision en-

\footnotetext{
${ }^{22}$ Article 7 of the Revised Family Code states that: 1) Neither a man nor a woman who has not attained the full age of eighteen years shall conclude marriage. 2) Notwithstanding the provisions of Sub-Article (1) of this Article, the Minister of Justice may, on the application of the future spouses, or the parents or guardian of one of them for serious cause, grant dispensation of not more than two years.

${ }^{23}$ Article 648 of the Criminal Code states that: Whoever concludes marriage with a minor apart from circumstances permitted by relevant Family Code is punishable with: 1) rigorous imprisonment not exceeding three years, where the age of the victim is thirteen years or above; or 2) rigorous imprisonment not exceeding seven years, where the age of the victim is below thirteen years.

${ }^{24}$ Previously, statutory rape was considered as crimes committed by males not by females. This results for the assumption that it occurs as a consequence of gender inequality in the society (see Driver \& Droisen, 1989: p. 138; Levine, 2006: pp. 1-39).
} 
sures the criminal liability of females, it only does so in situations where the woman causes the male minor to perform sexual intercourse with her. A contrario reading of this article indicates that, the woman is not liable if the minor male is the cause of the act, which is not the case in sub-article 1 of the same article since in the latter case the only requirement is the existence of sexual intercourse regardless of the cause of the action. Therefore, it is possible to argue that the Criminal Code does not provide equal protection to the male minor, which is also reflected in the penalties imposed in the two sub-articles.

The final provision of the Criminal Code covering issues of statutory rape is Article 627, which talks about "sexual outrages committed on infants". Sub-articles 1 and 2 of this article word by word reaffirm the provisions of sub-articles 1 and 2 of Article 626, respectively. The only difference between the sub-articles of Article 627 and Article 626 is on the age limit of the victim and the penalty imposed for the commission of the crime of statutory rape. While the age limit under the sub-articles of the former article is under the age of thirteen years, the age limit under the latter article is between the ages of thirteen and eighteen years. With regard to penalty, the former article impose severe penalty than the latter article, which shows the increment of severity of penalty as the age of the victim goes down. Therefore, the argument made above regarding different treatment between the girl and boy child continue to apply for infants below the age of thirteen.

All the articles so far discussed in this section talks about sexual intercourse with a minor below the age of eighteen years. These articles, however, does not expressly address between whom should the act be performed in order to be considered statutory rape. The glimpse view of Article 626 (2) of the Criminal Code seems that the act should be performed between a minor and an adult; because this article employed the word "woman" instead of "young woman" as used in Article 620 (2a) of the Criminal Code. Nevertheless, deeper scrutiny of the Amharic version, which is the governing version in case of contradiction with the English version, of Article 626 (2) of the Criminal Code shows otherwise. The Amharic version uses the phrase "andit siet" meaning a female rather that woman. Therefore, under the Ethiopian criminal law, statutory rape might be committed between minors of the opposite sex.

The final issue that could be addressed here is "whether sexual intercourse performed between two individuals below the age of consent is considered as statutory rape or not" under Ethiopian criminal law. The answer to this question depends on the forms of age of consent adopted by the state. For instance, if the state has a single age of consent, there is no possibility by which the act of minors below that age is legal (Glosser et al., 2004: pp. ES-2); but in a country that has not adopted a single age of consent, sexual relationship between minors may be considered as legal. Some states, for example, specify age ranges outside of which parties cannot consent to sex. In the District of Columbia, for instance, it is illegal to engage in sexual intercourse with someone who is under the age of 
consent (16 years) if the defendant is four or more years older than the victim. Thus, in Columbia, sexual relations between a 13-year-old and a 15-year-old would be legal even if both of them are under the age of consent since their age difference is less than four years (Ibid, pp. 5-8). As the writer try to show in the introductory part of this article, Ethiopia adopts a single age of consent, which is eighteen years of age. Hence, a male or female under eighteen years of age cannot consent to sex, regardless of the age of the other party. As a result, sexual relations between two minors would be illegal, as would relations between a minor and an adult, and thus is statutory rape. Here it should be noted that there is no minimum limit as to the age of the victim under the Criminal Code for the application of statutory rape. However, there is minimum age limit for a person to be held criminally responsible for any kind of crime, as stipulated in Article 52 of the Criminal Code. This article states that "infants who have not attained the age of nine years shall not be deemed to be criminally responsible". If the perpetrator attains the age of nine years, he/she will be held criminally responsible for the crime of statutory rape if he/she perform sexual intercourse with a person below the age of eighteen. Therefore, it is not necessary that the older juvenile held criminally responsible under the Ethiopian criminal law. What matters is the fulfillment of the conditions stated in Articles 620 (2a), 626 and 627 of the Criminal Code.

\section{Compatibility of Ethiopia's Statutory Rape Laws with Child Rights}

Children are physically and mentally immature. As a result, they are vulnerable and are dependent on adults for their basic needs. As a particularly vulnerable member of the society, children thus require and in fact deserve special protection. This has been given explicit recognition in the CRC and ACRWC. The CRC on its part states that, "bearing in mind that, as indicated in the Declaration of the Rights of the Child, the child, by reason of his physical and mental immaturity, needs special safeguards and care, including appropriate legal protection, before as well as after birth" (CRC, 1990: Preamble, para. 9). Similarly, the ACRWC stipulates that, "recognizing that the child, due to the needs of his physical and mental development requires particular care with regard to health, physical, mental, moral and social development, and requires legal protection in conditions of freedom, dignity and security" (ACRWC, 1999: Preamble, para. 6). This special need for protection also compelled states to provide protection at the domestic level. Accordingly, Ethiopia has enacted legislation meant to provide protection to the rights of children. Major among these is the 2004 Criminal Code. In this section, the writer tried to assess whether the Criminal Code provisions on statutory rape are compatible with the rights of children, particularly from the perspective of the right to equality.

The right to equality has been captured both in national legislations and transnational human rights treaties such that it has come to be part of an everyday vocabulary for national and international law making bodies (Takele: p. 66). It is recognized in different human rights instruments both at the transnation- 
al level and domestic level. Some instruments express it in the form of "non-discrimination clause" and some others in the form of "equality clause". For instance, the CRC obliges States Parties to respect and ensure the rights set forth in the present Convention to each child within their jurisdiction without discrimination of any kind, irrespective of the child's or his/her parent's or legal guardian's race, color, sex, language, religion, political or other opinion, national, ethnic or social origin, property, disability, birth or other status (CRC, 1990: Article $2(1))$. The right to equality here will come into picture only when there is discrimination in the enjoyment of those rights and freedoms explicitly guaranteed in the Convention (Takele: p. 75). Hence, the CRC enshrined the right to equality in the form of "non-discrimination clause". On the other hand, the Universal Declaration of Human Rights (UDHR) and the ICCPR incorporates the right to equality in the form of "equality clause"25. The UDHR under Article 7 provides that:

All are equal before the law and are entitled without any discrimination to equal protection of the law. All are entitled to equal protection against any discrimination in violation of this Declaration and against any incitement to such discrimination.

Similarly, Article 26 of the ICCPR stipulates that:

All persons are equal before the law and are entitled without any discrimination to the equal protection of the law. In this respect, the law shall prohibit any discrimination and guarantee to all persons equal and effective protection against discrimination on any ground such as race, colour, sex, language, religion, political or other opinion, national or social origin, property, birth or other status.

The main legal source for the right to equality under the FDRE Constitution is Article 25. It recognized the right to equality in the form of "equality clause". It states that:

All persons are equal before the law and are entitled without any discrimination to the equal protection of the law. In this respect, the law shall guarantee to all persons equal and effective protection without discrimination on grounds of race, nation, nationality, or other social origin, color, sex, language, religion, political or other opinion, property, birth or other status.

All those provisions that guarantee the right to equality in the form of "equality clause" contain two perspectives of equality: equality before the law and equal protection of the law. The former requires everybody to be considered equal in the eyes of the law, and thus advocates for the law to be neutral. The latter, on the other hand, require applicability of the protection guaranteed by the law to everybody without any kind of discrimination. This section thus tries to consider the statutory rape provisions of the Criminal Code from these two perspectives of equality.

${ }^{25}$ In fact, the UDHR under its Article 2 and the ICCPR under its Article 2 (1) also incorporated non-discrimination clause to ensure the right to equality. 
As outlined before, sexual intercourse with a minor, who is below the age of eighteen years, is illegal under the Criminal Code. The provisions concerning statutory rape under the Criminal Code are thus in line with Article 34 of the CRC and Article 27 of ACRWC. This enables for more comprehensive human rights based approach that takes into consideration the specific vulnerabilities based on both age and gender since there would have possibility to read them together in their enforcement. In addition, the advancement of the rights of children in the Criminal Code is also evidenced from the absence of a provision that allows for the discontinuation of prosecution in case when the criminal has conclude marriage with the victim, which was the case under the 1957 Penal Code of Ethiopia (Penal Code of Ethiopia, 1957: Article 599). Moreover, the raising up of the age of consent from 15 years to 18 years also lends some help in advancing the rights of children incorporated in the FDRE Constitution and recognized in the transnational human rights instruments ratified by Ethiopia. Furthermore, the criminally liability of females in the event where they are the cause of sexual intercourse with the male minor indicates to some extent, the laws neutrality in the protection of children though there is some drawbacks with regard to level of protection to boys and girls. This negates the traditional understanding of statutory rape as a crime that could happen only on females.

However, the Criminal Code has included different conditions for criminally liability of individuals for statutory rape and imposes different penalties for similar acts on the bases of gender. The existence of differences regarding the penalties and the conditions giving rise for criminal liability depending on the gender of the defendant indicates the failure of the Criminal Code in providing equal treatment and equal protection to male and female minors.

The equality before the law perspective of equality must be seen from the statutory rape provisions of the Criminal Code from the offenders' point of view. According to Article 626 (1) of the Criminal Code anyone who performs sexual intercourse with a girl child (between the ages of 13 and 18 years) or causes the latter to perform such an act with him, is punishable with rigorous imprisonment from three years to fifteen years. In addition, Article 627 (1) of the Criminal Code provides that whoever performs sexual intercourse with a minor of the opposite sex, who is under the age of thirteen years, or causes her to perform such an act with him, is punishable with rigorous imprisonment from thirteen years to twenty-five years. These two provisions are applicable when the offender is male and the victim is female. On the other hand, sub-article 2 of these two articles is applicable when male minors are victims and women are offenders. Accordingly, Article 626 (2) stipulates that a woman who causes a male minor between the ages of thirteen and eighteen years, to perform sexual intercourse with her, is punishable with rigorous imprisonment not exceeding seven years. Similarly, Article 627 (2) provides that a woman who causes a male minor under the age of thirteen years, to perform sexual intercourse with her, is punishable, with rigorous imprisonment not exceeding ten years. A comparison of the aforemen- 
tioned articles shows the violation of the equality before the law perspective of equality; because while the male offender is responsible in two situations, meaning for performing the act or causing the minor to perform the act, a woman offender is criminally responsible only when she cause a male minor to perform sexual intercourse with her. This would perpetuate the traditional/patriarchic view regarding the sexual aggressiveness of males and women's sexual passiveness and submissiveness. Besides, such would be against the aim of punishment, which does not consider gender difference.

The Equal protection of the law perspective on the other hand must be seen from the victims' point of view. As can be seen from the aforementioned provisions of the Criminal Code, the protection granted for male and female minors is different. In cases involving a female minor victim, the conditions for making the offender responsible is wider; i.e., what matters is the commission of the act regardless of the cause for the commission of the act. However, in cases involving a male minor victim, the cause for the commission of the act is determinant factor for criminal responsibility. In addition, the punishments are lenient when the victim is male minor as compared to that when the victim is female minor. ${ }^{26}$ This reflects the absence of equal protection of the law to male and female minors. This in turn would have two problems. First, it would be against the rationale for increasing the level of punishment, though some criminologists question the jurisprudence. One of the main rationales for the increase in the level of punishment is to deter the offender him/herself and others. This does not require the consideration of gendered conceptions rather the type of crime committed by the individual. Second, it is self-contradictory or a double standard to recognize the possibility for the commission of the crime by women and holding the traditional view at the same time.

Accordingly, the writer believe that, the statutory rape provisions of the Criminal Code have violated the right to equality before the law of male minors, which advocates for equal treatment of anyone in the eyes of the law. Hence, it can be argued that the rules governing statutory rape in Ethiopia are to some extent gendered. This, according to feminist legal scholars, violated a minor female's right to privacy and unfairly discriminated on the bases of gender (Levine, 2006: p. 5). They believe that, gendered statutory laws represent the government's attempt to oppress female minors as female minors because it indicates its inability to accept female sexuality (Greenfield, 1997: p. 8). Therefore, the existence of discrimination does not only fail to provide equal protection of the law to male minors but also affects the female minors by perpetuating the historical stereotypes and material realities existed on the lives of female children's among the society. This differentiation perpetuated outdated notions of the customary roles of the sexes and reinforced stereotypes of women as helpless and naive and of men as sexual aggressors (Levine, 2006: p. 9). To sum up,

${ }^{26}$ Compare the length of punishment provided under Article 626 (1) and 627 (1) with Article 626 (2) and 627 (2) of the Criminal Code, respectively. 
though the provisions governing statutory rape under the Criminal Code take into account the CRC and ACRWC, they fail to ensure the right to equality of children.

\subsection{The Practice}

So far, this article tries to pinpoint the legal gaps existed in the statutory rape provisions of the Criminal Code. Besides, there are cases that show improper application of those provisions by courts and prosecutors. This part of the article thus tried to show how courts and prosecutors applied the statutory rape provisions in some selected cases or how courts and prosecution offices provide protection to children using the Criminal Code. To this effect, an analysis is made on some court decisions and charges. The cases discussed here do not in any way represent the cross section of issues or decisions of courts and charges of prosecution offices, but are mere samples. The writer believes that those cases discussed hereunder throw light on the critical issues that need to be covered and show the trends.

The first case considered in this article is Case No. 71034. This case was presented before the Federal High Court in it appellate jurisdiction (See the details of this case in Tsehai, 2012: pp. 29-30). The case was first presented before the Federal First Instance Court. In this case, the defendant took the victim, a 17 years old female, to his house promising to marry her and she stayed there for a single night. An action for rape is instituted against the defendant and he was convicted and punished with 5 years of imprisonment. He instituted appeal before the Federal High Court arguing that the act was done upon consent. A medical report proved that an old defloration is observed. The court argued that the victim has contradicted her testimonies. The prosecution cannot prove violence and the act amounts to seduction, but not rape. As a result, the decision of the lower court was reversed on the ground that the act was done consensually.

As can be seen from the case, the victim is a 17 years old female minor. And according to Article 626 (1) a crime of sexual outrages on minors is committed when one performs sexual intercourse with a minor of the opposite sex... or causes her to perform such an act with him. Here consent is not a legal requirement for criminal liability. What matters is the making of sexual intercourse with the minor regardless of her consent. In fact, the defense raised by the defendant is correct since he was charged for the crime of rape. However, the court is required to order for the alteration of the charge as it contained essential errors (Criminal Procedure Code of Ethiopia, 1961: Article 119 (1)). Article 119 (1) of Criminal Procedure Code states that "where the accused is brought to trial on a charge containing essential errors or omissions... the court may at any time before judgment of its own motion or on application, order the charge to be altered or added to or a new charge to be framed, as the case may be. In the case at hand, taking the court's reasoning to reverse the decision of the lower court for 
granted, what the defendant committed was consensual statutory rape. Hence, his acquittal is not in line with the Criminal Code. In this case therefore the appellate court has committed an error in requiring the prosecution to prove the absence of consent. Besides, the prosecutor should not also base its charge solely on Article 620 (2a)) of the Criminal Code. Had the prosecution be made on the basis of Article 626 (1) of the Criminal Code, the alleged perpetrator might not be acquitted.

The other case is File No. 61711. It was first brought before Dilla City First Instance Court. In its charge presented to Dilla City First Instance Court, the prosecutor accused the defendant, a 16 years old boy, for committing a crime of rape against a 13 years old girl child in violation of Article 620 (2a) of the Criminal Code. The crime was alleged to have been committed on September 1, 2006 E.C. As stated in the charge, the defendant had invited the victim to visit his house and committed the alleged crime by making her incapable of resistance and despite her refusal to the action. After considering the evidences presented by both parties, the court acquitted the defendant as the prosecution fails to prove the absence of consent on the part of the victim. Aggrieved by this decision, the prosecution office had lodged an appeal before Gedeo Zone High Court wherein the decision of the lower court was reversed and seven years rigorous imprisonment ${ }^{27}$ has been imposed on the respondent (the then defendant). ${ }^{28}$ The respondent however presented a second appeal (an appeal over appeal) before SNNPRS Supreme Court opposing the decision of the first appellate court where the defendant were convicted for an attempt of rape contrary to Article 27 (1) and Article 620 (1a) of the Criminal Code and three years imprisonment was imposed on him countable from the first day of his incarceration.

As the issue relevant for this article was raised at Dilla City First Instance Court, the details of the proceeding at the appellate courts are not considered here. As indicated above, the first instance court has acquitted the defendant for the prosecution's failure to prove the absence of consent on the part of the victim. This happened due to the wrong approaches followed by the prosecution office in framing the charge and the strict adherence of the court to the charge. One of the major problems in the prosecution of the crime of rape is proving the absence of consent. As a result, the likelihood of losing the case is high. In such cases, instituting an alternative charge as per Article 113 (1) of the Criminal Procedure Code is crucial. This would enable the prosecutor to charge the defendant for the crime of statutory rape using Article 626 (1) of the Criminal Code, because in the latter case consent is not a legal requirement that should be proved for the conviction of the crime of statutory rape. Therefore, had the prosecution instituted an alternative charge, the defendant might not be acquit-

\footnotetext{
${ }^{27} \mathrm{By}$ considering the aggravating and mitigating factors, the court rests the punishment to be imposed on the defendant at level 26. Although the minimum punishment to be imposed on the defendant at this level is seven years and eight months imprisonment, the court only imposes seven years.

${ }^{28} \mathrm{At}$ this stage, the case was given 09787 as a file number.
} 
ted at first.

A similar approach was followed by the prosecution office in File No. 09810, which was presented before Dilla City First Instance Court. In this case, the public prosecutor has charged the defendant for a crime of rape committed against 12 years old. In the charge, the prosecutor alleges the absence of consent on the part of the victim and basis its action on Article 620 (2a) of the Criminal Code. ${ }^{29}$ In this case, the prosecutor has committed a couple of errors. Firstly, the stated legal provision is applicable only when the victim of the crime of rape is between the age of thirteen and eighteen years of age. Second, as argued above, proving the absence of consent in the prosecution of the crime of rape is difficult, and making the likelihood of losing the case very high. To avoid it, it would have been better had prosecution instituted an alternative charge against the defendant for the crime of statutory rape on the basis of Article 627 (1) of the Criminal Code.

The issue of statutory rape has been also reached to the attention of the Federal Supreme Court through the cassation procedure. The relevant case in this regard is Cassation File No. 46412. This case was first instituted before the High Court of Harari National Regional State. In this case, the defendant was charged with the crime of rape committed against a 15 years old girl in violation of Article 620 of the Criminal Code. The crime was alleged to have been committed on November 07, 2000 E.C around 4:00 O'clock of the night at a place called Nede Gobe. As stated in the charge, the defendant committed the alleged crime by the use of violence and grave intimidation and after having rendered her unconscious or incapable of resistance though the defendant pleaded not guilty. However, the court acquitted the defendant as per Article 141 of the Criminal Procedure Code and based on the argument that the prosecution witnesses and evidence confirms that the defendant performed sexual intercourse with the alleged victim consensually and not forcibly.

Aggrieved by this decision, the prosecution office had lodged an appeal before the Supreme Court of Harari National Regional State. After considering the case, the Harari Supreme Court confirmed that the defendant has performed sexual intercourse on the alleged victim. However, it framed the issue whether the crime alleged to have been committed falls within the ambit of Article 620 of the Criminal Code. After noting that the age of the defendant and the alleged victim was 16 and 15 years old, respectively, at the time of the commission of the alleged crime, the Harari Supreme Court has confirmed the acquittal decision of the Harari High Court. However, the Harari's Supreme Court justification to reach at this conclusion is different from the High Court. The Harari Supreme Court has argued that the Criminal Code is silent regarding this kind of situa-

\footnotetext{
${ }^{29} \mathrm{~A}$ similar approach was followed by the prosecution office in cases brought before Dilla City First Instance Court at different times. For instance, in File No. 09810 and File No. 10585 the defendants were charged for the crime of rape allegedly committed against 14 years old girl in violation of Article 620 (2a) of the Criminal Code and for the crime of attempted rape allegedly committed against a 13 years old girl child in violation of Article 27 (1) and Article 620 (2/a/) of the Criminal Code, respectively.
} 
tions and the court is not allowed to create crimes by analogy as per Article 2 (3) of the Criminal Code, and thus acquitted the defendant.

The prosecution office however presented a cassation petition before the Federal Supreme Court opposing the decision of the lower courts and claiming their decision have a fundamental error of law. In particular, the petition submits that the decisions of the lower courts do not consider the intention and contents of Articles 2 (3), 56, 211 and 626 of the Criminal Code and Article 113 (2) of the Criminal Procedure Code and thus demands the court to find the defendant in violation of Article 626 (1) of the Criminal Code and requested to defend. After considering arguments of the parties, the petitioned decisions and the relevant laws, the Cassation Bench of the Federal Supreme Court has framed the issue as "whether the acquittal of the respondent is legal or not".

As indicated in the cassation decision, it is a proved fact by both the Harari High Court and Harari Supreme Court that the respondent was 16 years old at the time of the commission of the crime and has performed sexual intercourse with a 15 years old girl child. However, the respondent's legal counsel, in his written argument, has contended before the Cassation Bench that existence of sexual intercourse between the two was not proved though the Cassation Bench rejected the contention arguing that it lacked jurisdiction to review the lower court's decision on assessment of evidences as per Article 80 (3a) of the FDRE Constitution and Article 10 of Federal Courts Establishment Proclamation No. 25/1996.

As shown above, the respondent was acquitted by the Harari Supreme Court with the reason that Article 626 (1) of the Criminal Code is silent in cases where the victim and the perpetrator are within the age range of 13 and 18 years. However, the Cassation Bench argued that the word "whosoever" in Article 626 (1) of the Criminal Code should be viewed in consideration of the provisions of the Criminal Code that talks about criminal responsibility (Article 48 to 56). More specifically it should be read in line with Article 56 of the Criminal Code, which makes young person's between the age ranges of 13 to 18 years criminally responsible. The Supreme Court, therefore, argued that there is no legal justification to exonerate the respondent from criminal responsibility owing to his age. The Supreme Court further argued that the main focus of Article 626 (1) of the Criminal Code is making those persons performing sexual intercourse with a minor girl or causes her to perform such an act criminally responsible. The fact that the perpetrator is within the age range of 13 to 18 years does not relieve him from criminal responsibility rather the victim as per Article 211 (1) of the Criminal Code. It further says that, the aim of the law is not exonerating persons performing sexual intercourse from criminal responsibility by the mere fact that the alleged victim and the perpetrator are within the age range of 13 to 18 years. It is believed that the aim of the law is protecting children's within these age ranges from being exposed to inappropriate conduct. The Supreme Court thus argued that, the invocation of Article 2 (3) of the Criminal Code by the appellate court 
was mistaken. If it was proved that the respondent has performed sexual intercourse with a 15 years old girl and if it was found that the act is less than what is stated in the prosecution charge, as per Article 113 (2) of the Criminal Procedure Code, he should have been required to defend in light of Articles 56 and 626 (1) of the Criminal Code. The respondent's acquittal decision of the lower courts without requiring him to defend therefore contains a fundamental error of law as it was in violation of Articles 56, 211 and 626 (1) of the Criminal Code and aims of the Criminal Code. The Court thus reversed the lower court's decision on the matter and remanded the case for retrial as per Article 195 (2a) of the Criminal Procedure Code.

It is important to see the issues in this case separately at each level of the court. Accordingly, the High Court of Harari National Regional State, the Harari Supreme Court, and the Federal Supreme Court Cassation Bench decisions are considered successively herein below.

The Harari High Court, as indicated above, has acquitted the defendant for the reason that the prosecution witnesses and evidence confirmed that the defendant performed sexual intercourse with the alleged victim consensually and not forcibly. As said before in the analysis of File No. 61711 presented before Dilla City First Instance Court, this happened due to the wrong approaches followed by the prosecution office in framing the charge and the strict adherence of the court to that charge. As indicated above, had the charge been framed on the basis of Article 626 (1) of the Criminal Code or had the prosecution instituted an alternative charge as per Article 113 (1) of the Criminal Procedure Code, the court might not acquit the defendant. The action of the prosecution office and the Court would thus affect the children's interest intended to be protected by the Criminal Code.

As indicated above, the Harari Supreme Court has tried to investigate "whether the crime alleged to have been committed falls within the ambit of Article 620 of the Criminal Code or not". It then concludes that since both the alleged victim and the defendant are between the age ranges of 13 to 18 years, it cannot be covered in the stated provision. It further erroneously argued that the Criminal Code is silent when both the victim and the defendant are within these age ranges. As rightly stated by the cassation decision of the Federal Supreme Court, the Harari Supreme Court has mistakenly applied Article 2 (3) of the Criminal Code and consequently acquitted the defendant. Therefore, it is possible to argue that the Harari Supreme Court has framed the issue properly but reached at the wrong conclusion.

As said before, the Federal Supreme Court in its cessation decision has rightly rejected the Harari Supreme Court interpretation of the Criminal Code on the matter, especially with regard to the invocation of Article 2 (3) of the Criminal Code by the latter court. However, surprisingly, the Federal Supreme Court has also committed a couple of errors. Firstly, it improperly applied the provision of Article 211 (1) of the Criminal Code. The particular of the cassation decision 
shows that this article was used to exclude the victim from criminal responsibility though the provision does not talk about issue of exclusion of criminal responsibility. This article rather deals with the body empowered to bring legal action in criminal cases. Article 211 (1) of the Criminal Code states that "prosecution with a view to a judgment and the enforcement of the penalty is a public proceeding and is instituted by the public prosecutor in all cases where the law does not otherwise expressly provide". The Federal Supreme Court thus erroneously applied Article 211 (1) of the Criminal Code for this case. Secondly, the Federal Supreme Court correctly ruled out the acquittal decision of the Harari Supreme Court arguing that there is no legal justification to exonerate the respondent from criminal responsibility owing to his age. It also rightly argued that the aim of the law is protecting children's within the age range of 13 to 18 years from being exposed to inappropriate conduct. However, it narrowly interpreted Article 626 of the Criminal Code and considers it as if it provides protection only to the girl child. The mere fact that the respondent was having sexual intercourse with the alleged victim may not necessary make him criminally responsible alone. As stated in Article 626 (2) of the Criminal Code, if the woman causes a male minor to perform sexual intercourse with her, she is criminally responsible. Therefore, there is a possibility by which both may be held criminally responsible though the Federal Supreme Court disregarded this fact.

The last relevant case under consideration here is File No. 10544, which was presented before Dilla City First Instance Court. In this case, the defendant was charged for a crime of rape committed against a 14 years old girl in breach of Article $620(2 / \mathrm{a} /)$ of the Criminal Code. Unlike the aforementioned cases, the court in this case has done a good job by ordering the prosecution to amendment the charge to Article 626 (1) of the Criminal Code as per the power given to it by Article 119 (1) of the Criminal Procedure Code.

All the discussions so far made shows that the trends in the courts and prosecutors regarding the application of provisions dealing with the crime of statutory rape are inconsistent. In some cases, both tend to prove the existence or otherwise of the "consent" element in the adjudication of cases of involving crime of statutory rape. As indicated before, this would negatively affect the proper implementation of the rights of children. This could also bring international responsibility on the state as it would result for failure to comply with its obligations towards children. However, there are also situations where both have done well in applying those provisions.

\section{Concluding Remarks}

Statutory rape is a criminal act emanated from the performance of sexual intercourse between persons among whom one or both are under the age of consent. Statutory rape laws are based on the premise that until a person reaches the age of majority, that person is legally incapable of consenting to sexual intercourse. These laws essentially negate the young person's ability to engage voluntarily in 
sexual intercourse by subjecting the minor's partner to a criminal penalty. In Ethiopia, the Criminal Code includes provisions that address the crime of statutory rape. Accordingly, children under the age of eighteen years are not legally able to engage in sexual intercourse. The justification for such measure is that such activity can cause both physical injury and serious psychological damage in addition to the violation of the rights and freedoms of the victim enshrined in different human rights instruments.

However, though governments have an obligation to protect people within its jurisdiction from violence by taking appropriate steps, which include among others measures that aim at deterring and preventing crime, they are required to do so within the human rights framework (Human Rights Watch, 2007: p. 90 as cited in Erooga, 2008: p. 173). The Criminal Code takes into account the provisions of the CRC and ACRWC concerning the prohibition of any sexual activities with minors, which are relevant in the furtherance of the rights of children. In addition, it has made some positive changes on the 1957 Penal Code that are very relevant for the better protection of the rights of minors. For instance, non-prosecution in the event of subsequent marriage is totally disregarded and the age of consent is raised to eighteen years. Thus, the essential elements of a human rights based approach to legislative reform for providing effective protection to children include among others legislations aimed at eliminating the disadvantages faced by children is highlighted in the Criminal Code. Moreover, the criminal law is not also concerned with the gender of the parties to the sexual intercourse rather on the protection of children from sexual abuse and exploitation. The Criminal Code is now gender neutral with regard to the offence of statutory rape in that it can be committed by a person of either sex. It focuses. Nevertheless, its failure to provide equal legal protection to minors and to treat offenders of the crime of statutory rape differently is the drawbacks that would hinder the enhanced protection of children.

In addition to the legal gaps, there are practical loopholes that results for the improper application of the statutory rape laws. This, as observed from the cases dealt within this article, results from the lack of knowledge on the part of some court personnel and prosecution officers regarding the legal requirements necessary to handle statutory rape cases, and lack of awareness on the part of victims. Given the consequence of statutory rape on minors, however, there should be frameworks by which the criminal justice system would respond to this crime properly. This among others requires the enhancement of the legal awareness of those personnel and agencies working on child protection issues. The government should endeavor to create awareness among the public in general and potential victims of statutory rape in particular. Sensitization of the law among law enforcement agencies should be considered as well.

Although the Ethiopian statutory rape law makes criminalization of the act gender neutral, it definitely is in need of a rethinking for it leaves some loopholes regarding the treatment of offenders and the protection of minor victims. 
Accordingly, the law needs to incorporate provisions that show its gender neutrality with regard to the protection of minor victims as well as the treatment of offenders. In this regard, it is recommended that the situations by which all criminals of statutory rape are responsible should be made gender neutral. In addition, the punishments for statutory rape should not take gender into consideration. To this effect, Article $626(1 \& 2)$ and Article 627 (1\&2) of the Criminal Code should be amended in a manner showing their gender neutrality. For instance, the provisions of Article 626 sub-article 1 and sub-article 2 might be merged and improved in either of the following manner:

- Whoever performs sexual intercourse with a minor of the opposite sex, who is between the ages of thirteen and eighteen years, or causes the opposite sex to perform such an act with him/her, is punishable with rigorous imprisonment from three years to fifteen years. or

- Whoever causes the opposite sex, who is between the ages of thirteen and eighteen years, to perform sexual intercourse with him/her, is punishable with rigorous imprisonment not exceeding seven years.

The writer recommends the first alternative as it is more proper to serve the underlining idea of criminalizing statutory rape, which is to give protection to minors for whom consenting to sexual activity is problematic or to minors who are too naive to comprehend fully the act of sexual intercourse. With these recommendations, it will be hoped that the statutory rape law of Ethiopia will enhance the realization of rights of children and serve all in equality.

\section{Acknowledgements}

I would like to extend my heartfelt appreciation to the editorial staff of the BLR and the anonymous reviewers for their important remarks and constructive comments. The errors left uncorrected remain my own.

\section{References}

(1957). Penal Code of Ethiopia, Proclamation No. 158/1957.

(1960). Civil Code of Ethiopia, Proclamation No. 65/1960.

(1961). Criminal Procedure Code, Proclamation No. 185.

(1966). International Covenant on Civil and Political Rights.

(1966). International Covenant on Economic, Social and Cultural Rights.

(1981). African Charter on Human and Peoples' Rights.

(1989). Convention on the Rights of the Child.

(1990). African Charter on the Rights and Welfare of the Child.

(1995). FDRE Constitution, Proclamation No. 1.

(2000). The Revised Family Code, Federal Negarit Gazetta, Extra Ordinary Issue No. 1/2000, Proclamation No. 213/2000.

(2004). Criminal Code of the Federal Democratic Republic of Ethiopia, Proclamation No. 414/2004. 
Alston, P. (1992). The Legal Framework of the Convention on the Rights of the Child. In Bulletin of Human Rights. Geneva: Centre for Human Rights.

Carpenter, C. L. (2003). On Statutory Rape, Strict Liability, and the Public Welfare Offense Model. American University Law Review, 53, 313-391.

Christopher, R. L., \& Christopher, K. H. (2007). Adult Impersonation: Rape by Fraud as a Defense to Statutory Rape. Northwestern University Law Review, 101, 75-122.

Christopher, R. L., \& Christopher, K. H. (2012). The Paradox of Statutory Rape. Indiana Law Journal, 87, 505-549.

Daniels, M., \& Dan, E. (1998). Statutory Rape: When Adults Prey Sexually upon Children. A Report on Protecting the Children of Massachusetts, Massachusetts Family Institute.

Donovan, P. (1997). Can Statutory Rape Laws Be Effective in Preventing Adolescent Pregnancy? Family Planning Perspectives, 29, 30-34 + 40.

Driver, E., \& Auderey, D. (1989). Child Sexual Abuse: Feminist Perspective. Basingstoke: The Macmillan Press Ltd.

Elias, N. (2013). Principles of Ethiopian Criminal Law.

Elste, S. G., \& Noy, D. (1997). Sexual Relationships between Adult Males and Young Teen Girls: Exploring the Legal and Social Responses. American Bar Association Center on Children and the Law.

Erooga, M. (2008). A Human Rights-Based Approach to Sex Offender Management: The Key to Effective Public Protection? Journal of Sexual Aggression, 14, 171-183.

Girmachew, A., \& Yonas, B. (n.d.). Handbook on the Rights of the Child in Ethiopia.

Glosser, A. et al. (2004). Statutory Rape: A Guide to State Laws and Reporting Requirements. The Lewin Group.

Greenfield, M. (1997). Protecting Lolita: Statutory Rape Laws in Feminist Perspective. Women's Law Journal, 1, No. 1.

Hanzi, R. (2006). Sexual Abuse and Exploitation of the Girl Child through Cultural Practices in Zimbabwe: A Human Rights Perspective. LLM Dissertation, University of Pretoria.

Henry, M. D., \& Scott, C. (2009). Do Statutory Rape Laws Work?

Levine, K. L. (2006). No Penis, No Problem. Emory University School of Law Public Law \& Legal Theory Research Paper Series, Research Paper No. 05-37.

McCabe, K. A. (2003). Child Abuse and the Criminal Justice System. New York, NY: Peter Lang Publishing.

Mower, A. G. (1997). Convention on the Rights of the Child: International Law Support for Children. London: Greenwood Press.

Muringa, G. (2005). Violence against Women and the Law in Burundi: Towards a More Protective System. Research Partnership 3/2004. The Danish Institute for Human Rights.

Norman, S. et al. (2003). Statutory Rape Laws by State: OLR Research Report.

Steel, J. et al. (2004). Psychological Sequlae of Childhood Sexual Abuse, Related Characteristics Coping Strategies and Attribution Style' Child Abuse and Neglect.

Takele S. (n.d.). The Interplay of the Equality Clause and Affirmative Action Measures under the Ethiopian Constitution: The Benishangul Gumuz Case and Beyond.

Tsehai, W. (2012). Rethinking the Ethiopian Rape Law. Journal of Ethiopian Law, 25, No. 2. 